\title{
Quantitation of oestrogen receptors: use of solid-phase antisteroid antibodies to quantify binding sites and determination of dissociation constant
}

\author{
S RAAM AND JL COHEN
}

From Tufts University Medical Cancer Unit, Lemuel Shattuck Hospital, 170 Morton Street, Boston, Massachusetts 02130, USA

SUMMARY The dextran-coated charcoal assay method of McGuire and DeLaGarza is a well-known method for quantitation of oestrogen receptors in breast tumour tissues. Castañeda and Liao reported that the solid-phase antisteroid antibodies are superior to dextran-coated charcoal for quantitating the receptor bound steroids. In this report we compare the results obtained using both methods to quantitate oestrogen receptors and determine the affinity for steroid binding in seven human breast tumours and the uteri of rat and calf.

Several methods are available for the quantitation of steroid receptors in the cytosol of breast tumours. The dextran-coated charcoal method developed by McGuire and DeLaGarza ${ }^{1}$ serves as a useful technique not only for the quantitation of the receptor sites but also for estimating the affinity of the receptors for the steroid. Detection and quantitation of the oestradiol binding $8 \mathrm{~S}$ and $4 \mathrm{~S}$ components by sucrose-density gradient centrifugation ${ }^{2}$ provides an alternate method. Dextran-coated charcoal and sucrose-density gradient methods have been compared for their relative merits by several groups of investigators. $^{3}$

The use of immobilised antibodies ${ }^{4}$ has been introduced as a new method for the quantitation of the steroid receptors. Our laboratory employs the dextran-coated charcoal assay for routine detection, quantitation, and affinity estimation of the oestradiol receptors in human breast tumours. This paper describes the results of a series of receptor studies in which we have compared the results of immobilised antisteroid antibody assay with those of dextrancoated charcoal assay and evaluated the merits of the former as a routine clinical test procedure.

\section{Material and methods}

After surgical excision the tumours were kept on ice, trimmed of fat, and transported to the laboratory on dry ice. The specimens were stored in liquid nitrogen

Received for publication 8 October 1979 until ready to be used. Pulverisation, homogenisation, and cytosol preparation were all done according to the procedure of McGuire and DeLaGarza. ${ }^{1}$

QUANTITATION OF OESTRADIOL BINDING SITES AND ESTIMATION OF DISSOCIATION CONSTANT (Kd) OF THE REACTION

Dextran-coated charcoal assay

McGuire and DeLaGarza ${ }^{1}$ protocol was followed. One hundred microlitres of tumour cytosol or of calf uterus $(1-2 \mathrm{mg} / \mathrm{ml}$ protein concentration) were incubated in duplicates with $50 \mu \mathrm{l}$ of ${ }^{3} \mathrm{H}$ oestradiol of different levels of concentrations varying from 0.01 pmol to $0.2 \mathrm{pmol}$ per $50 \mu \mathrm{l}$. For the assessment of non-specific binding of oestradiol, the cytosol was incubated with $0.2 \mathrm{pmol}$ of ${ }^{3} \mathrm{H}$ oestradiol and 200 fold excess of unlabelled competitor diethylstilboestrol. After overnight incubation at $0-4^{\circ} \mathrm{C}$, protein-bound ${ }^{3} \mathrm{H}$ oestradiol was separated from the unbound steroid by $500 \mu \mathrm{l}$ dextran-coated charcoal solution. The amount of receptor bound ${ }^{3} \mathbf{H}$ oestradiol and bound over free steroid ratio were calculated for each concentration of ${ }^{3} \mathrm{H}$ oestradiol, and the values were analysed by Scatchard analysis.

\section{Antibody-Sepharose method}

Cyanogen bromide-activated Sepharose 4B was purchased from Pharmacia, Sweden, and anti-17 $\beta$ oestradiol antiserum from Research Plus Inc, USA. Sodium sulphate precipitated antiserum proteins were coupled to activated Sepharose following the procedure of Castañeda and Liao. ${ }^{4}$ 
One hundred microlitres of cytosol $(1-2 \mathrm{mg} / \mathrm{ml}$ protein) were incubated for 6 hours with $50 \mu \mathrm{l}$ of increasing concentrations of ${ }^{3} \mathrm{H}$ oestradiol $(0 \cdot 015-0 \cdot 2$ pmol per $50 \mu \mathrm{l})$. All incubations were carried out in flat-bottomed AutoAnalyzer vials (Fisher Scientific, USA). Anti-oestradiol-antibody coupled to Sepharose was used to separate receptor-bound oestradiol from the free oestradiol. Two hundred microlitres of the antibody-Sepharose suspension formed a thin layer at the bottom. The total volume of the incubation mixture containing the cytosol and the labelled oestradiol never exceeded $150 \mu \mathrm{l}$. Subsequent to the addition of the antibody Sepharose suspension, the total volume of the mixture was $350 \mu \mathrm{l}$, and under these conditions the antibodySepharose was able to bind $85-90 \%$ of the free oestradiol in the absence of competing receptor protein. The steroid-binding capacity of $200 \mu \mathrm{l}$ antibody-Sepharose was tested for different concentrations of the radiolabelled steroid used in the assay $(0.015-0.2 \mathrm{pmol} / 50 \mu \mathrm{l})$. Our results showed that shaking the vials containing the Sepharose beads leads to sticking of the beads to the sides of the tubes. Therefore difficulties were experienced in getting a clear supernatant for counting the radioactivity. Because of additional concern about fragmentation of the beads, we avoided both the centrifugation and shaking steps.

For each steroid concentration, the amount of radiolabelled steroid left in the supernatant of vials containing buffer, antibody, and ${ }^{3} \mathrm{H}$ oestradiol was subtracted from the total radiolabel found in the supernatant of the vial containing cytosol, antioestradiol antibody, and ${ }^{3} \mathrm{H}$ oestradiol.

For both dextran-coated charcoal and antibodySepharose methods, low affinity, high capacity, nonspecific binding sites were estimated by the method outlined by McGuire and DeLaGarza ${ }^{1}$ using unlabelled diethylstilboestrol as a competitor.

\section{Results}

The Scatchard plots obtained for one of the tumours by the antisteroid antibody method and the dextrancoated charcoal methods are shown in the Figure.

Data obtained on binding sites per mg protein and $\mathrm{Kd}$, using both methods, are compared and tabulated in Table 1A and B. There is good agreement between the values for estimated sites per mg cytosol protein for all the samples assayed by both methods. $\mathrm{Kd}$ values were all found to be in the same range as those described by other investigators for oestrogen receptors. ${ }^{1}$ The agreement in results for both assays is true for animal tissues as well as human breast tissue (Table 1B).

\section{Discussion}

Castañeda and $\mathrm{LiaO}^{4}$ reported the use of immobilised antisteroid antibodies to detect and quantitate steroid receptors in rat prostate and uterine cytosols. They presented evidence to show that the specific receptor-steroid complexes are not precipitated by the antisteroid antibodies whereas free steroid molecules as well as steroids non-specifically bound to non-receptor proteins are precipitated by antisteroid antibodies. Their postulate is based on the relative affinities for the protein binding of the steroids which are in the descending order of receptor $>$ antibody $>$ other non-specific steroid binding proteins. Furthermore, it was suggested that the assay for steroid receptors by adsorption techniques using dextran-coated charcoal may present complications resulting from the non-specific adsorption of specific receptor protein, thus leading to an underestimation of binding sites. ${ }^{4}$ In order to test whether there is a discrepancy between the two methods in quantitation of receptor sites we compared the adsorbant method with the antibody technique. Our

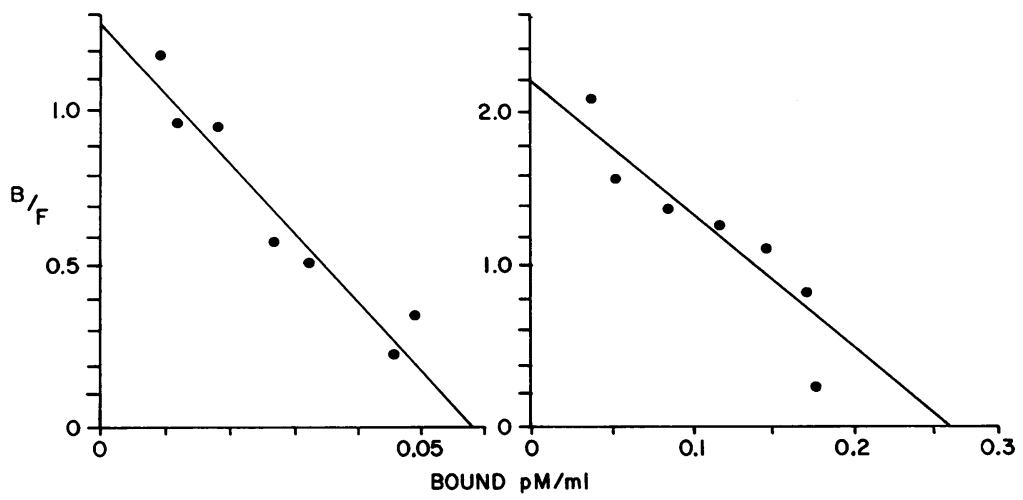

Scatchard analysis of oestrogen receptors in the breast tumour cytosol of patient PL: (left) Antibody-Sepharose method: oestrogen binding sites $=387$ fmol per mg protein; $K d=1.8 \times 10^{-10} \mathrm{M}$; (right) Dextran-coated charcoal method: oestrogen-binding sites $=371$ fmol per mg protein; $K d=1.8 \times 10^{-10} \mathrm{M}$ 
Table 1 Oestradiol receptor quantitation: comparison of antibody Sepharose method and dextran-coated charcoal method

\begin{tabular}{|c|c|c|c|c|}
\hline & \multicolumn{2}{|c|}{ Antibody-Sepharose method } & \multicolumn{2}{|c|}{ Dextran-coated charcoal method } \\
\hline & $f m ! m g$ protein & $(K d) \times 10^{-10} \mathrm{M}$ & $\mathrm{fm} / \mathrm{mg}$ protein & $(K d) \times 10^{-10} \mathrm{M}$ \\
\hline \multicolumn{5}{|c|}{ (A) Human breast tumours } \\
\hline MG & 421 & 1.9 & 429 & $5 \cdot 7$ \\
\hline PL & 387 & $1 \cdot 8$ & 371 & 1.8 \\
\hline ET & 97 & $7 \cdot 2$ & 84 & 1.6 \\
\hline AG & 38 & 4.9 & 31 & 0.8 \\
\hline SA & 50 & $2 \cdot 2$ & 46 & $1 \cdot 6$ \\
\hline${ }^{*} \mathbf{A N}$ & 0 & - & 0 & - \\
\hline${ }^{*} \mathrm{LS}$ & $\mathbf{0}$ & - & $\mathbf{0}$ & - \\
\hline \multicolumn{5}{|c|}{ (B) Uterus } \\
\hline Calf & 116 & 0.72 & 191 & $0 \cdot 59$ \\
\hline Rat & 280 & $1 \cdot 2$ & 360 & 0.9 \\
\hline
\end{tabular}

*Non-specific steroid binding was observed by both the methods, and appropriate corrections were made. Values obtained for non-specific binding for patients AN and LS are as follows:

$A N=30 \mathrm{fm} / \mathrm{mg}$ protein by antibody-Sepharose method and $14 \mathrm{fm} / \mathrm{mg}$ protein by DCC method

LS $=38 \mathrm{fm} / \mathrm{mg}$ protein by antibody-Sepharose method and $18 \mathrm{fm} / \mathrm{mg}$ protein by DCC method

experimental design allowed the estimation of the total steroid accessible sites and the affinity of the receptors of the ligand.

Our data clearly indicate that the dextran-coated charcoal method and antibody-Sepharose method similarly measure the specific receptor-steroid complexes. The binding affinity of the receptors measured by both methods is also found to be within the range found by the previous workers for the oestradiol-receptors of human breast tumour cytosol. ${ }^{2}$ Further, in the tumour cytosols with no specific binding (patients AN and LS-Table 1A), we could detect no significant difference between the two methods in the ability to estimate non-specific binding components in the presence of excess of DES. Both in the dextran-coated charcoal method and in the antibody-Sepharose method, the oestradiols bound to non-specific proteins (low affinity, high capacity) are left in the supernatant.

In conclusion, while the antisteroid antibody assay yields results comparable to the dextran-coated charcoal technique, it does not provide any apparent advantages over the dextran-coated charcoal method.

\section{References}

${ }^{1}$ McGuire WL, DeLaGarza M. Improved sensitivity in the measurement of estrogen receptors in human breast cancer. J Clin Endocrinol Metab 1973;37:986-9.

${ }^{2}$ Wittliff JL, Savlov D. Estrogen binding capacity of cytoplasmic forms of estrogen receptors in human breast cancer. In: McGuire WL, Carbone PP, Vollmer EP, eds. Estrogen Receptors in Human Breast Cancer. New York: Raven Press, 1975.

${ }^{3}$ Hahnel R, Vivian AB. Biochemical and clinical experience with estimation of estrogen receptors in human carcinoma. In: McGuire WL, Carbone PP, Vollmer EP, eds. Estrogen Receptors in Human Breast Cancer. New York: Raven Press, 1975:205-35.

${ }^{4}$ Castañeda $\mathrm{E}$, Liao $\mathrm{S}$. The use of anti-steroid antibodies in the characterisation of steroid receptors. J Biol Chem $1975 ; 250: 883-8$.

Requests for reprints to: Dr S Raam, Tufts University Medical Cancer Unit, Lemuel Shattuck Hospital, 170 Morton Street, Boston, Mass 02130, USA. 